\title{
GEORGE VICTOR DU NOYER'S CAREER IN THE ORDNANCE AND GEOLOGICAL SURVEYS (1835-69): GEOLOGIST BY PROFESSION, ARTIST BY TEMPERAMENT
}

\author{
SUSAN HegaRTY* \\ School of History and Geography, Dublin City University \\ [Accepted 15 February 2018. Published xx August 2018.]
}

\begin{abstract}
George Victor Du Noyer (1817-69) was among the surveyors employed by the Geological Survey of Ireland (GSI) shortly after its foundation in 1845. He was one of several menantiquarians, artists, recorders of nineteenth century life - whose interest went beyond geology. This paper explores Du Noyer's development as a geologist, and his transformation from artist to geologist. It discusses Du Noyer's career in both the Ordnance and the Geological Surveys and considers his relationships with his superiors-relationships that were at times marked by a profound loyalty, while at other times involving a certain amount of tension, and always driven by the personalities involved. The paper also considers the motivation behind Du Noyer's presentation of albums of sketches to the Royal Irish Academy.
\end{abstract}

\section{Introduction}

The early nineteenth century witnessed an explosion of scientific and cultural associations across Britain. ${ }^{1}$ This trend was similar in Ireland. While some of these bodies were scholarly_ such as the Royal Irish Academy, the Royal Dublin Society-others, such as the Ordnance Survey, were part of the apparatus of the state. These state agencies oftentimes had military personnel at the helm, but they also employed civilians. In the case of the Ordnance Survey of Ireland, many of the civilians employed were antiquarians who possessed a particular interest in archaeology, language, culture and with preserving the past of Ireland. Many were involved in scholarly bodies, such as the Royal Irish Academy, and the various archaeological societies that were established as nationalist ideals gained momentum and the material cultures of the past were appealed to by nationalists to foster a sense of identity. ${ }^{2}$

One of these scholars was George Victor Du Noyer (1817-69), whose life and achievements have attracted renewed interest in recent years; the bicentenary of his birth in 2017 saw the first major exhibition of his work in 20 years. ${ }^{3}$ His vivid depictions of everyday life, his landscapes and geological sections offer an insight into the landscape and everyday life of Ireland and those who inhabited the land before, during and after the Great Famine of 1845-49- though he did not chronicle this event directly in any of his works. His sketches

\footnotetext{
*Author's e-email: Susan.Hegarty@dcu.ie doi: https://doi.org/10.3318/PRIAC.2018.118.08

${ }^{1}$ David Cahan, 'Looking at nineteenth-century science: an introduction', in David Cahan (ed.), From natural philosophy to the sciences: writing the history of nineteenth-century science (Chicago, 2003), 3-4.

${ }^{2}$ Elizabeth Crooke, Politics, archaeology and the creation of a national museum of Ireland: An expression of national life (Dublin, 2000), 17-18.

${ }^{3}$ Stones, Slabs and Seascapes: George Victor Du Noyer's Images of Ireland; Crawford Gallery Cork 17 Nov. 2017-24 Feb. 2018. A smaller version of this exhibition was displayed by the National Museum of Ireland, Collins Barracks, Dublin from March to September 2018.
} 
and watercolours, which number over a thousand, act almost as a visual record to his journey as a draughtsman first and a geologist in his later life.

This paper will address the career development of Du Noyer. Previous work has outlined Du Noyer's life and his contribution to the cultural scene of Ireland in the early and mid-nineteenth century. ${ }^{4}$ However there has been no attempt to date to engage in a detailed investigation into his development as a geologist, which would trace the transition from his initial training as a watercolour artist to his career as a geologist and his appointment to the Geological Survey of Ireland. Furthermore, there has been a lack of inquiry into the motivation behind why Du Noyer, while working as a geologist, continued to sketch and paint so proficiently and with such prolificity.

Du Noyer was in many ways a quintessentially Victorian gentleman, albeit one without independent wealth. He was born in 1817 in Blackrock, county Dublin, into a family of Huguenot descent; his forbearers first arrived in Ireland in the 1780s. ${ }^{5}$ By the time Du Noyer was ten years old, the family had relocated to Dublin city where his father taught French and his mother ran a school for young ladies from their home, something they had previously done in Blackrock. ${ }^{6}$ Both parents thus catered for the fashion of the wealthier members of late eighteenth and early nineteenth-century Dublin society to educate their children in the French language. ${ }^{7}$ Conscious of the importance of a good education if he was to succeed in society, Du Noyer was sent by his parents to school with the Rev. William Jones, who ran a 'Seminary for General Education' in Great Denmark Street, where he excelled in drawing and writing, as well as excelling naturally in French. ${ }^{8}$ From this early stage springs Du Noyer's connection with George Petrie (1789-1866) with whom Du Noyer studied and who was to exercise a deep influence on his life and interests. Petrie, the son of an artist, had been educated in the drawing school of the Dublin Society; he became particularly skilled in landscape watercolour, and he had acquired an interest in archaeology during his teenage years. ${ }^{9}$ Petrie instructed the young Du Noyer in the techniques of the watercolourist, and imbued in him his precision and faithfulness to the natural landscape as well as his love of archaeology and antiquities. Petrie later ran the topographical section of the Ordnance Survey out of his home - called TeePetrie — at 21 Great Charles' Street, Dublin, where he also kept a very large collection of antiquities. ${ }^{10}$

Du Noyer's coming of age coincided with a surge in inquiry and scientific endeavour. In 1824 the Ordnance Survey of Ireland was set up as a branch of the Ordnance Survey of Britain with the purpose of producing accurate maps of Ireland. Although run by the military, under the influence of Major Thomas Colby (1784-1852) who wished to create a broader survey than merely that sufficient to produce six-inch maps, the Ordnance Survey of Ireland employed civilians to survey and collect information about placenames, statistics, antiquities, geology and other elements of the landscape. Originally this information was to be collected

\footnotetext{
${ }^{4}$ Petra Coffey, 'George Victor Du Noyer 1817-1869: artist, geologist and antiquary', Journal of the Royal Society of Antiquaries of Ireland, 123 (1993), 102-199, provides a comprehensive biography. Fionnuala Croke, George Victor Du Noyer 1817-1869: Hidden Landscapes, (Dublin, 1995); Peter Murray, Stones, Slabs and Seascapes: George Victor Du Noyer's images of Ireland (Cork, 2017) focus more on his visual archive.

${ }^{5}$ Coffey, 'George Victor Du Noyer', 102.

${ }^{6}$ Saunders's News-Letter, 13 Jan. 1825, 4; Croke, George Victor Du Noyer 1817-1869, 11.

${ }^{7}$ Márie Kennedy, French books in eighteenth-century Ireland (Oxford, 2001), 22-37; James Kelly, 'Educational print and the emergence of mass education in Ireland, c.1650-c.1830', in James Kelly and Susan Hegarty (eds), Schools and Schooling, 1650-2000: New Perspectives on the History of Education (Dublin, 2017), 58.

${ }^{8}$ Dublin Evening Packet and Correspondent, 12 July 1834, 1; Croke, George Victor Du Noyer 1817-1869, 103.

${ }^{9}$ Paul Walsh, 'George Petrie: his life and work', in Próinséas Ní Chatháin and Siobhán Fitzpatrick with Howard Clarke (eds) Pathfinders to the Past: The antiquarian road to Irish historical writing 1640-1960 (Dublin, 2012), 44-71; David Cooper, 'Petrie, George', in James McGuire and James Quinn (eds), Dictionary of Irish Biography (9 vols., Cambridge, 2009), viii, 81-4.

${ }^{10}$ Gillian M. Doherty, The Irish Ordnance Survey: history, culture and memory (Dublin, 2004), 60-1.
} 
into memoirs accompanying the maps of each county. ${ }^{11}$ However, a lack of funding meant that only one of these memoirs was published within the timeframe. ${ }^{12}$ The employment of civilians to the Ordnance Survey began in the 1830s.

\section{Du Noyer's geological formation at the Ordnance Survey}

Du Noyer commenced his employment as a civilian assistant in the Ordnance Survey on 6 April 1835 . He was 18 years and his salary was $2 s .6 d$. a day. ${ }^{13}$ He was initially deployed in the orthography section, in which John O'Donovan (1806-61) had been working since October 1830. ${ }^{14}$ In the following months, George Petrie was recruited to the staff of the Ordnance Survey, on a salary of 10 shillings a day, which was the highest salary for a civilian assistant. ${ }^{15}$ As Du Noyer began his employment at the Ordnance Survey before Petrie, it is unclear whether Petrie secured the young Du Noyer a post at the Survey, as has been suggested. ${ }^{16}$ Petrie had met John O'Donovan in 1831 and acted as an advisor to O'Donovan's orthography section of the Ordnance Survey prior to being formally employed. ${ }^{17}$ It is possible, therefore, that Petrie mentioned Du Noyer, highlighting his artistic ability, to O'Donovan, who then recommended Du Noyer to Larcom for a position on the Survey. ${ }^{18}$ On his formal appointment to the Ordnance Survey, Petrie became, in effect, the line-manager of O'Donovan and Du Noyer, although Du Noyer and Petrie worked together only briefly. Du Noyer quickly made an impression on his employers, as can be seen by his salary which rose from $2 s .6 d$. a day in May 1835 to $4 s$. a day in September of the same year. ${ }^{19}$ By that time he was no longer employed in the orthography section, leaving vacant a space which would be occupied by Eugene O’Curry (1794-1862).

Du Noyer was posted 'when still quite a boy' to the geological branch of the Ordnance Survey. ${ }^{20}$ In the return for November, Du Noyer is listed as among those who were part of the geological and trigonometric division headed by Captain Joseph Ellison Portlock (1794-1864), recording the geology in the field. ${ }^{21} \mathrm{He}$ was to remain in this section until he left the Ordnance Survey, apart from three months back at the orthography section towards

\footnotetext{
${ }_{11}$ J.H. Andrews, A paper landscape: the Ordnance Survey in nineteenth-century Ireland (Dublin, 2001), 14479; Doherty, The Irish Ordnance Survey, 38-40.

12 T.F. Colby, Ordnance survey of the county of Londonderry. volume the first: memoir of the city and north western liberties of Londonderry, parish of Templemore (Dublin, 1837).

${ }^{13}$ National Archives of Ireland (NAI), Ordnance Survey/1/12, Monthly returns of Civil Assistants employed on the Ordnance Survey of Ireland who receive $2 s$. or more than $2 s$. per diem for the month of May 1835.

${ }^{14}$ NAI, Ordnance Survey/1/12, Monthly return of civil assistants, sappers and miners and inferior assistants employed at Mountjoy, 31 May 1835.

${ }^{15}$ NAI, Ordnance Survey/1/12, Monthly returns of Civil Assistants employed on the Ordnance Survey of Ireland who receive $2 s$. or more than $2 s$. per diem for the month of Aug. 1835.

${ }^{16}$ Rob Bohan, Linde Lunney, 'Du Noyer, George Victor', in McGuire and Quinn (eds),

Dictionary of Irish Biography, iii, 489-90.; Petra Coffey, 'George Victor Du Noyer - artist and geologist (181769)' in Murray and Coffey, Stones, Slabs and Seascapes, 14. It is interesting to note that Petrie joined on a higher salary than O'Donovan, although O'Donovan had been with the Survey for a number of years at that point. O'Donovan's salary fluctuated between $7 s$. and $9 s$. a day, and at that point was $8 s$.: NAI, Ordnance Survey/1/12, Monthly return of civil assistants, sappers and miners and inferior assistants employed at Mountjoy, 31 Aug. 1835. The following month, O’Donovan is recorded as having a salary of $10 s$. - equal to that of Petrie.

${ }^{17}$ Walsh, George Petrie: his life and work, 49-50.

${ }^{18}$ Petrie's influence on hiring within the Ordnance Survey may also explain the presence of William Wakeman, another art student of George Petrie, who was employed in the Ordnance Survey in 1838.

${ }^{19}$ NAI, Ordnance Survey/1/12, Monthly return of civil assistants employed on the Ordnance Survey who receive $2 s$. or more than $2 s$. per diem for the month of Sept 1835.

${ }^{20}$ George Henry Kinahan, 'Obituary-G.V. Du Noyer', Geological Magazine, 1869, 94.

${ }^{21}$ NAI, Ordnance Survey/1/12, Return of Civil assistants employed in Captain Portlock's department for the month of November 1835 .
} 
the end of his time at the Ordnance Survey. Thus, his work at the Ordnance Survey became Du Noyer's apprenticeship for his later work with the Geological Survey.

\section{Part of Portlock's team}

Joseph Ellison Portlock was an enthusiastic and exacting scientist and founding member of the Geological Society of Dublin in 1831. His love of and affinity for geology resulted in his election as president of the Geological Society of London in 1857 and 1858, by which time he was one of the leading figures in the geological community in early nineteenth-century Britain. ${ }^{22}$ Thus, from the outset of his time in the Ordnance Survey, Du Noyer worked closely with one of the most able geologists of the day. Portlock and his team were charged with producing a geological map and report of the geology of the island of Ireland, beginning in the north. Du Noyer was employed variously in the field or in the office within the geological division (also called the geological department). While at first he seems to have formed part of the team undertaking the trigonometrical survey that was initially linked to the geological work of the division, mostly he was employed to examine and sketch the geology, and towards the end of his service he was exclusively employed to draw geological sections, fossils and landscapes. Thus, although located within the geological section, he was employed primarily for his artistic skill, which was put to full use. Sketching is an important part of the 'toolkit' of a geologist - the ability to pick out patterns and sequences within rock and sediment sections is a first step to investigating the processes that lead to the deposition of sedimentary rock, the emplacement of igneous or the deformation of metamorphic rocks. At a time when geology was at its infancy, the ability to sketch accurately and generalise trends seen within rock sections and the physical landscape in general was paramount. The artistic ability of Du Noyer, his evident speed in recording detail and his accuracy meant that he was soon a key part in Portlock's team, which embarked on recording the geology of Ireland for the first time.

Portlock and his geological division were also expected to feed into the county memoirs proposed by Colby and Sir Thomas Aiskew Larcom (1801-79), the lieutenant effectively at the head of the Ordnance Survey in Ireland. The memoirs required illustrations, which necessitated someone who could sketch the geology as well as items of antiquarian interest and produce lithographs. The difficultly of producing a product which Portlock would stand over, given the tight schedule and limited finances, would ultimately prove insurmountable for the geological mapping project in the Ordnance Survey. ${ }^{23}$

Because Portlock's returns to the geological department are not as complete as many of the returns of his peers, it is not possible to establish a detailed record of Du Noyer's 'geological' exploits during his early term in the Ordnance Survey. On most of the returns, Du Noyer was noted as being employed as an artist sketching geological specimens. The first half of 1837 saw Du Noyer on 'geological duties' in the field, along with James Flanagan (who would later also form part of the staff on the Geological Survey) and sixteen others. ${ }^{24}$ Du Noyer was on the third highest salary of the civilians working within Portlock's section of the Ordnance Survey at this stage, indicating his centrality to the project Portlock was embarked on, or perhaps Portlock's perception of what this project entailed. By July, Du

\footnotetext{
${ }^{22}$ Roderick Murchison, 'Address to the Royal Geographical Society' containing an obituary of Major General J. Portlock, The Journal of the Royal Geographical Society of London, 34 (1864), p. cxvii; G.L. Herries Davies, Sheets of Many Colours (Dublin, 1983), 97.

${ }^{23}$ Andrews, A paper landscape, 154-79.

${ }^{24}$ NAI, Ordnance Survey/1/14, Monthly return of civil assistants employed in the geological and trigonometric department, Jan. to May 1837. Flanagan was among the first employed within the geological division, earning $2 s$. $6 d$. a day from Jan. 1833. NAI, Ordnance Survey/1/9, Monthly return of civil assistants, sappers and miners and inferior assistants employed at Mountjoy, 1-31 Jan. 1833.
} 
Noyer's geological duties had brought him back into the office to work on sketches, where he remained for the rest of the year. ${ }^{25}$ By November 1837 Portlock was returning more complete reports of the activities of the Geological Department to headquarters (although this was short-lived and somewhat sporadic). These reports allow us to identify in greater detail what Du Noyer was engaged in while assigned to office duties within the Geological Survey. In November 1837, Du Noyer was busy making 'drawings of three specimens of fish, three of trilobites, three of zoophytes, two varieties of apples, arranging specimens of recent and fossil crustacea, and also arranging and labelling rocks', ${ }^{26}$ while in December 1837 , having spent the previous month sketching, Du Noyer was 'examining, classifying, arranging, drawing and setting up objects of natural history'. ${ }^{27}$ In February and March 1838, when he was again in the field, he was employed 'making sections' at Faughanvale in the barony of Tirkeeran in county Londonderry, as well as 'classifying and arranging catalogues of natural things' in the office in Belfast. ${ }^{28}$ Du Noyer's primary employment, therefore, continued to be that of an artist, with Portlock putting his artistic skill to full use both in the office and in the field.

In February 1838 Du Noyer was joined in the field by Thomas Oldham (1816-78), a recently arrived civilian recruit to the Ordnance Survey, who went on to become the second director of the Geological Survey of Ireland and under whom Du Noyer would be appointed to this body. Meanwhile, and until his departure from the Ordnance Survey in 1842, Du Noyer's skill as an artist was availed of the maximum. In April 1838, he was employed 'making geological drawings' in Banagher and Dungiven. ${ }^{29}$ This set the pattern for what would henceforth be termed 'making geological and other drawings' ${ }^{30}$ Yet, Du Noyer continued to combine geological sketching with his interest in antiquities during this time. In July 1838, he was listed as 'drawing specimens of antiquities' in Lower Killybegs in county Donegal (a county where no other member of his department was working). ${ }^{31}$ This also shows the fluidity and interdependence of the various divisions of the Ordnance Survey memoir project.

All this time, Du Noyer was effectively engaged in what amounts to an informal apprenticeship in the new science of geology with one of that subject's greatest proponents. In his personal journal of late 1839, Du Noyer mentions four times his being in the field with Portlock, ${ }^{32}$ for whom he sketched fossils, sections and some illustrative views. ${ }^{33}$ Portlock was so taken with Du Noyer's sketching skills that he named a fossil after him:

\footnotetext{
${ }^{25}$ NAI, Ordnance Survey/1/14, Monthly return of civil assistants employed in the geological department, July 1837.

${ }^{26}$ NAI, Ordnance Survey/1/14, Nov. 1837, Progress report of the geological department of the Ordnance Survey of Ireland, commanded by Captain Portlock.

${ }^{27}$ NAI, Ordnance Survey/1/14, Dec. 1837, Progress report of the geological department of the Ordnance Survey of Ireland commanded by Captain Portlock.

${ }^{28}$ NAI, Ordnance Survey/1/15, Feb. 1838, Progress report of the geological department of the Ordnance Survey of Ireland commanded by Captain Portlock.

${ }^{29}$ NAI, Ordnance Survey/1/15, Apr. 1838, Progress report of the geological department of the Ordnance Survey of Ireland commanded by Captain Portlock

${ }^{30}$ NAI, Ordnance Survey/1/15, Monthly reports of geological department, April, May, June, Aug., Sept., Oct., Nov. 1838; NAI Ordnance Survey/1/16, Monthly reports of geological department, Jan., Feb., April, May, June, July (when he was one day absent), Aug., Sept., Oct., Nov., Dec. 1839.

${ }^{31}$ NAI Ordnance Survey/1/15, Monthly reports of geological department, July 1838.

${ }^{32}$ National Library of Ireland (NLI), 1441, G.V. Du Noyer, Private journal, entries for 12 and 16 July, and 29 and 30 Oct. 1839.

${ }^{33}$ Joseph Ellison Portlock, Report on the geology of the county of Londonderry and of parts of Tyrone and Fermanagh, (Dublin and London, 1843), ix.
} 
Lucina Du Noyeri - Dedicated to Mr George Du Noyer, whose skill in drawing- the fossils delineated in this report, and whose other merits, deserve to be commemorated. ${ }^{34}$

It is possible that Portlock's meticulous character found an echo in Du Noyer. Thomas Colby's comment in February 1840 that 'in truth geology has run too much into fossils-is too much made up of minute research - and has not yet a sufficiently obvious connection with utility', while not written specifically of Du Noyer, could just as easily have been written about him as of Portlock. ${ }^{35}$ Indeed, Colby noted to Larcom later that same year that

This semi-survival of the memoir will I fear do little good - there can be no doubt but our friend Portlock has a great deal of geological knowledge of Ireland-But I much fear he will not give it in a condensed form. ${ }^{36}$

Colby was more interested in mapping the geology for its economic benefit rather than for the science of geology itself, and grew impatient with Portlock's failure to meet his demanding schedule. ${ }^{37}$

This meticulousness was to cost Portlock's project dear. By 1840, the geological division was in jeopardy due to rising costs, and the delay in publication of a memoir led to the recall of many of those working on the geological survey. In May 1840 Du Noyer spent 26 days at the Dublin headquarters of the Ordnance Survey in Mountjoy, in what was clearly a signal to Portlock since location in the office was cheaper than having a geologist in the field. ${ }^{38}$ When the geological section of the Ordnance Survey was depopulated in mid-1840, Du Noyer moved to the orthography branch and working under Petrie in July 1840, when his 'employment [within the geological department] was suspended'. ${ }^{39}$ His health evidently suffered with this change, and for the first time on record he went on sick leave in August $1840 .{ }^{40}$ In September he was back in the field, as he wrote to Captain Larcom in September from Cahir, county Tipperary having completed the first list of sketches that O'Donovan had asked him to undertake. ${ }^{41}$ O'Donovan further requested Du Noyer, in October of 1840, to sketch a 'stone idol' found 18 years previously at the entrance to Cormac's chapel in Cashel. ${ }^{42} \mathrm{He}$ was still in county Tipperary at the end of October, from where he wrote a letter to Petrie about the sketch he had completed for O'Donovan of the stone idol. ${ }^{43}$

As the divisions in which he worked became depopulated, Du Noyer was anxious to raise his profile as an illustrator through publishing his work beyond the Ordnance Survey. While in county Tipperary, Du Noyer produced sketches of Holy Cross abbey and Cahir Castle, which he thought could be usefully published in The Irish Penny Journal, which Petrie edited. He wrote to Petrie:

I wish to ask you if the appearing of them in the Penny Journal would or could bring down on me the censure of Capt. L[arcom] — though I made the sketches

\footnotetext{
${ }^{34}$ Portlock, Geology of Londonderry, 572.

${ }^{35}$ NLI, 7555, Larcom Papers, Thomas Colby to Larcom, 18 Feb. 1840.

${ }^{36}$ NLI, 7555, Larcom Papers, Thomas Colby to Larcom, 16 July 1840.

${ }^{37}$ Andrews, A Paper Landscape, 169.

${ }^{38}$ NAI, Ordnance Survey/1/17, Monthly returns of the Civil Assistants in the geological department, May 1840.

${ }^{39}$ NAI, Ordnance Survey/1/17, Monthly returns of the Civil Assistants in the geological department, July 1840.

${ }^{40}$ NAI, Ordnance Survey/1/17, Monthly returns of the royal sappers, miners etc. employed at Mountjoy, Aug. 1840 .

${ }^{41}$ Royal Irish Academy (RIA), 24 39/JOD/81, G. V. Du Noyer to Captain Larcom, 25 Sept. 1840.

${ }^{42}$ RIA, 12 N 5/36, John O’Donovan to George Petrie, 3 Oct. 1840.

${ }^{43}$ RIA, 12 N 5/37, G.V. Du Noyer to George Petrie, Cashel, 26 Oct. 1840.
} 
from which the drawings have been taken at times which did not in the least interfere with my duty. Yet those set in authority over me may not be charitable enough to think I really did so. [...] I leave the matter entirely to your better judgement - perhaps by delaying their publication for some time they might appear without implicating me. ${ }^{44}$

Unsigned engravings of the two sites did appear in the Irish Penny Journal the following year, which suggests that Petrie thought it wise to follow Du Noyer's suggestion and not 'implicate' him in the sketches. ${ }^{45}$ Indeed, it would appear that Larcom had concerns over Du Noyer's continuous sketching taking away from his duty at the Survey. It is notable that Du Noyer was careful, in the letter he wrote to Larcom in September of 1840, to recount his whereabouts and actions for each day; evidently he was nervous of Larcom's perception of him, as his letter to Petrie attests. ${ }^{46}$

Du Noyer was again transferred to the geological department on 23 December 1840. He spent the next six months assisting in the production of illustrations for Portlock's Memoir of Londonderry. ${ }^{47}$ Colby wrote to the inspector general of the Ordnance Survey in his quarterly returns for June 1841:

Captain Portlock has not yet completed his Geological Memoir for publication; and he has deemed the extension of some enquiries into the county of Fermanagh essential to its perfection. I have therefore directed him to send me a distinct statement of every such addition he requires that I may apply for any requisite authority to enable me to expedite the publication of the Memoir. ${ }^{48}$

At this point, only five people remained employed on the Geological Survey with Portlock Flanagan, Oldham, Du Noyer, John Ferguson (whose role was to collect information on mineral statistics) and Thomas Douglas (office duties). ${ }^{49}$ By November 1841, Ferguson had been redeployed within the Orthography division as a messenger, with the result that the geological department limped along with the four remaining members, working with their captain. ${ }^{50}$ In February 1842 Du Noyer was crossed off the list of civil assistants to the Ordnance Survey, along with Thomas Oldham, James Flanagan and Thomas Douglas ${ }^{51}$. Nonetheless, Portlock continued to avail of Du Noyer (and Flanagan, Oldham and Douglas) on an occasional basis as he sought to complete his memoir. Thus, in November 1842, Portlock stated that 'Mr Du Noyer [was employed for six days] to draw fossils required to be referred to in the text'. ${ }^{52}$ But while Oldham and Flanagan were re-employed by the Ordnance Survey for the geological department in 1842, Du Noyer was only employed casually, and

\footnotetext{
${ }^{44}$ RIA, 12 N 5 /40, G.V. Du Noyer to George Petrie, Cashel, 20 Nov. 1840.

${ }^{45}$ Cahir Castle, Co. Tipperary, Irish Penny Journal, 33 (13 Feb. 1841); Holy Cross Abbey, Co. Tipperary, Irish Penny Journal, 38 (20 March 1841).

${ }^{46}$ RIA, 24 O 39/JOD/81, G.V. Du Noyer to Captain Larcom, Cahir, 25 Sept. 1840; RIA 12 N 5/40, G.V Du Noyer to George Petrie, Cashel, 20 Nov. 1840.

${ }^{47}$ NAI, Ordnance Survey/1/17, Monthly returns of the royal sappers, miners etc. employed at Mountjoy, Dec. 1840 .

${ }^{48}$ NAI, Ordnance Survey/1/18, Colonel Colby to the Inspector General of Fortifications reporting the Progress of the Survey of Ireland during the quarter ending 30 June 1841.

${ }^{49}$ NAI, Ordnance Survey/1/18, Monthly return, geological department, June 1841.

${ }^{50}$ NAI, Ordnance Survey/1/18, Monthly return, geological department, Nov. 1841.

${ }^{51}$ NAI, Ordnance Survey/1/19, Monthly return of civil assistants, Feb. 1842. It is noteworthy that the names are struck-through. In most other cases, it gives the reason for leaving (resignation / dismissal etc.) but in the case of these four names, there is no record.

52 NAI, Ordnance Survey/1/19, Monthly returns, geological department, Nov. 1841.
} 
then by Portlock himself. January 1843 was the final time that Portlock's name appeared in the monthly return of officers employed on the Survey of Ireland - and it was joined by that of Captain Henry James. ${ }^{53}$ Around the same time, the total number of civil assistants was dramatically reduced. That spelled the formal end of Du Noyer's association with the Ordnance Survey. Although employed in the geological section, Du Noyer remained an artist to the end, while engaged in sketching also some archaeological features, and pursuing what was, in effect, an informal geological apprenticeship.

It was the meticulousness shown in the constant search for perfection by Portlock, and the costs associated with it, which hastened the downfall of the geology section of the Ordnance Survey, and ultimately of the Memoir project as a whole. It is no surprise, given the loyalty shown by Du Noyer to Portlock's project, to read the assessment of M. Alphonse Gages, M.R.I.A. and later curator of the museum of the Royal College of Science of Ireland, in his biographical notice of Du Noyer's death, that Portlock 'remained ever afterwards his protector and his friend'. ${ }^{4}$ After Portlock's death in 1864, his widow, writing to Du Noyer, requested that he oversee the transfer of Portlock's library of over one thousand volumes on geology, palaeontology, mineralogy and natural history (books in French and German as well as in English) to the offices of the Geological Survey of Ireland.$^{55}$ The fact that she would do so twenty years after he left the Ordnance Survey is a testament to the bond that existed between Portlock and Du Noyer.

Thus Du Noyer's period with the Ordnance Survey truly constituted an apprenticeship. While there, he also engaged his interest in archaeology. He sketched the antiquity collection of Colonel William Stewart of Killymoon castle at the end of August $1839^{56}$, and other archaeological finds he encountered on his travels, such as those within the parish of Maghera, sketched on 6 August $1839,{ }^{57}$ or the 'bones and teeth found my me in the Giant's Grave' at Laughery Demesne, county Tyrone, later that year. ${ }^{58}$

From a background in drawing, Du Noyer had become, almost without his wishing it, part of the geological community. His interest in geology piqued, he became a member of the Geological Society of Dublin in 1843, and a council member of the organisation the following year. By the time that he was first employed by the Geological Survey, he had produced plates for Fredrick McCoy and Richard Griffith's A synopsis of the characters of the Carboniferous limestone fossils of Ireland (1844), and perhaps more significantly, had gone beyond solely sketching and had read a paper on the geology of west Clare at the Geological Society of Dublin in $1846 .{ }^{59}$ Du Noyer, therefore, had begun to be regarded as a geologist, as he was now presenting original research at the local Geological Society-the distinction between professional and amateur geologist at this time being non-existent. In fact, regional geological societies between $c .1830$ and $c .1860$ were created as places where people could receive a geological formation as well as present on their understanding of the geology of particular areas. ${ }^{60}$

\footnotetext{
${ }^{53}$ NAI, Ordnance Survey/1/20, Monthly return of Officers employed on the Survey of Ireland, January 1843.

${ }^{54}$ M.A. Gages, 'Biographical Notice of the late George V. Du Noyer, M.R.I.A.', Proceedings of the Royal Irish Academy (PRIA), 10 (1866 - 1869), 413.

${ }^{55}$ Geological Survey of Ireland (GSI), Outgoing letters 1862-78/76-9.

${ }^{56}$ NLI, 1441, G.V. Du Noyer, Private journal, entries for 30 and 31 Aug. and Sept. 2, 5, 6, 7 and 9 1839. See also Sharon A. Greene, 'A pair of latchets drawn by Du Noyer in 1839.' Ulster Journal of Archaeology, 62 (2003), 179-180, www.jstor.org/stable/20568326.

${ }^{57}$ NLI, 1441, G.V. Du Noyer, Private journal, entry for 6 Aug. 1839.

${ }^{58}$ NLI, 1441, G.V. Du Noyer, Private journal, entry for 3 Oct. 1839.

${ }^{59}$ Croke, 13.

60 J.G. O'Connor and A.J. Meadows, 'Specialisation and professionalization in British geology' in Social Studies of Science, 6:1 (1976), 83-4.
} 
Although Du Noyer left the Ordnance Survey in 1842, the formation he received there would never leave him, as many of the ideals espoused by his peers in the Ordnance Survey had become his own. Indeed, the seeds of the Geological Survey of Ireland were sown in Portland's geological department of the Ordnance Survey. Of the initial geologists recruited to the Geological Survey of Ireland, three-Thomas Oldham, James Flanagan and George Victor Du Noyer - had previously been employed in the geological department of the Ordnance Survey. With the discipline of geology still in its infancy, the training that these men received within the Ordnance Survey, and indeed their friendship, was to prove fundamental for their future careers, and they remained friends to the end. When Flanagan was gravely ill in Ballyhale, county Kilkenny in March 1859, Du Noyer 'thought it his duty' to let a colleague know that Flanagan was 'sinking rapidly' and anxiously wished to see him. ${ }^{61}$ The bond formed among Portlock's men proved enduring, and this strong bond extended to their relationship with their leader.

\section{Between artist and geologist}

After his departure from the Ordnance Survey, Du Noyer worked as what might be called a freelance artist for four years. Like Petrie, he produced many monochrome sketches which would later be engraved for use as illustrations in books. ${ }^{62}$ He produced drawings for the Halls' Ireland, its scenery, character etc. (published in three volumes, 1841-43) and in 1845 provided illustrations for Petrie's The ecclesiastical architecture of Ireland anterior to the Anglo-Norman invasion, with an essay on the round towers of Ireland. He sketched and lithographed an image of the Royal Hospital Kilmainham that was used as the frontispiece for Rev. R.N. Burton's history of the hospital in $1843 .{ }^{63}$ Also in 1843, he exhibited three watercolours at the Royal Irish Art Union in Dublin, which were sold for between $£ 5$ and $£ 7 .{ }^{64}$ In the same year, he was placed second in the lithography competition at the Royal Irish Art Union. During this time, therefore, he was evidently working to make ends meet, plying his trade as an artist and illustrator.

After some time spent freelancing, Du Noyer secured a regular income as a tutor at $\mathrm{St}$ Columba's school, then located in Stackallen House, county Meath. St Columba's had as one of its principal objectives the promotion of the Irish culture and language, in part as a proselytising effort to prepare Anglicans to take part in the church's missions in the west of Ireland. ${ }^{65}$ The college, founded in 1843, employed a native Irish speaker, John T. Coffey, a scholar of Irish at Trinity College, to instruct the boys in Irish and in 1844 employed Du Noyer to teach drawing. The school had also commissioned John O'Donovan to write an Irish grammar 'for the use of the higher classes'. ${ }^{66}$

During this time Du Noyer continued to sketch antiquities, becoming part of the community of antiquarians in Dublin, as William Hackett of Cork related to John Windele after an encounter with Du Noyer in late 1844: 'I did meet him at the R.I. Academy and we were three hours in earnest archaeological colloquy - he is very young, for one of us, and from what I could glean of him is not thought so much of. He practises his old pursuit of the brush with marvellous facility: several of Petrie's illustrations were drawn by him'. Hackett

\footnotetext{
${ }^{61}$ Royal Society of Antiquaries (RSAI), G.V. Du Noyer sketches, notebook 5, 5 Mar. 1859.

${ }^{62}$ William Stokes, The life and labours in art and archaeology of George Petrie (London, 1868), 11; Peter

Murray, 'George Victor Du Noyer-where and when', in Murray, Stones, slabs and seascapes, 55-7.

${ }^{63}$ Nathanael Burton, History of the Royal Hospital, Kilmainham (1843).

${ }^{64}$ A.M. Stewart, Irish Art Loan Exhibitions 1765-1927, Index of Artists Vol I, A-L (Dublin, 1990), 205.

65 Justyna Pyz, 'St Columba's College: an Irish school in the age of empire', in David Dickson, Justyna Pyz and Christopher Shepard (eds), Irish classrooms and British empire: imperial contexts in the origins of modern education (Dublin, 2012), 125.

${ }^{66}$ The British Magazine and Monthly Register of Religious and Ecclesiastical information (1844), 419.
} 
went on to relate Du Noyer's knowledge of and theories about Newgrange, as 'he lives very near that great monument and often visits it' ${ }^{67}$ This was not Du Noyer's first visit to the Royal Irish Academy. He had been there the previous July, when he passed the time sketching ladies' shoes (complete with details of the material and colour of each of the parts). ${ }^{68}$

Meanwhile, Du Noyer continued to hone his artistic skills. In 1844 he wrote to Petrie from Stackallen, enclosing a sketch of Ardmulchan church:

Would you tell me if you think I have improved in colouring in the drawing of Dunmore Castle which I sent to the Exhibition. I cannot so well judge of my own work as another person, and one so competent to give an opinion as you are. I wish to improve - and can only hope to do so. [...] If you have time to say a few words regarding this drawing I would be very grateful. But of course would not wish to impose anything on you which would interfere with your important work. ${ }^{69}$

The exhibition to which Du Noyer refers was at the Royal Hibernian Academy of Arts (RHA), where he displayed his watercolour of 'Dunmore Castle on the Boyne, near Navan' in $1844 .^{70}$ This was just one of seventeen watercolours that Du Noyer exhibited at the RHA that year; he followed this with seven additional watercolours in 1845. Du Noyer's perception of himself at this time was evidently as an illustrator and artist, in contrast to later in his life, when he would sign as a geologist. ${ }^{71}$ Du Noyer appears to have stopped exhibiting his artwork in public in 1847, on his appointment to the Geological Survey of Ireland-perhaps in an effort to focus his attention, as well as the attention of others, on his work as a geologist. He returned to exhibiting and selling work in 1860, possibly to supplement his income, two years after his marriage to Frances Adelaide du Bedat, his first cousin and the daughter of William George du Bedat (1818-89), transfer officer of the Bank of Ireland. William Du Bedat possessed a number of Du Noyer's sketches, including at least one watercolour, and lent two for display in the Art Exhibition of the Royal Dublin Society in 1858. By 1860, when Du Noyer returned to selling his work at exhibition, the Du Noyer family was growing, and therefore the extra income would have been welcome. ${ }^{72}$ The Geological Survey did not provide funds to assist with the moving of an entire family as geologists moved about the country. Therefore, as Du Noyer's family grew, financial pressures mounted.

\section{Stepping back to geology}

Du Noyer stayed at St Columba's until December 1845, by which point he was anxious to spread his wings and to find a more congenial employment that might suit better his temperament, and perhaps be better paid. In July 1845, he was introduced to Henry De la Beche (1796-1855), the first director of the Geological Survey of Great Britain and Ireland by Oldham, who was then professor of geology at Trinity College, Dublin. The Geological Survey of Great Britain and Ireland, which was based in London, was established in May of that year, with De la Beche at the helm. In his letter of appointment to the role, De la Beche

\footnotetext{
${ }^{67}$ RIA 12 L 9/24(i), William Hackett to John Windele, 24 and 27 Dec. 1844.

${ }^{68}$ RSAI, G.V. Du Noyer sketches, notebook 2, July 1844.

${ }^{69}$ RIA 12 N 5, 60, G.V. Du Noyer to George Petrie, 12 May 1844.

70 A.M. Stewart, Royal Hibernian Academy of Arts, Index of Exhibitors and their works 1826-1979, Vol 1 A-G (Dublin, 1985), 237.

${ }^{71}$ In Thom's Irish Almanac and Official Directory, 1847, Du Noyer is categorised as an artist, while in Thom's Irish Almanac and Official Directory, 1864, he is listed as a geologist.

${ }^{72}$ Stewart, Royal Hibernian Academy of Arts, 237.
} 
was encouraged to appoint geological assistants to the survey of Great Britain from among the 'body of geologists already organised' and engaged in geological mapping for the Ordnance Survey of Great Britain. That new geological survey was to be extended to Ireland, 'probably by the same persons', and under Captain Henry James, who was seconded to the position of local director in Dublin. ${ }^{73}$ The geologists were employed on the understanding that they could be moved between surveys as the director requested. The summer of its establishment, Oldham wrote to De la Beche asking him to show Du Noyer around London as he was visiting the city for the first time. From Oldham's remarks it is clear that Du Noyer intended settling in London, possibly securing a position within the new Geological Survey there, and Oldham recommended his old companion to De la Beche as someone who 'possesses powers as a draughtsman [...] which I have never seen excelled, and to the most upright principles and gentlemanly feelings with a quickness of observation and originality of idea which would make a most valuable aid' ${ }^{74}$ De la Beche must have subsequently met Du Noyer, as evidenced in a subsequent (and more subdued) letter by Oldham to De la Beche, which speaks of De la Beche knowing Du Noyer. ${ }^{75}$

\section{A geologist with the Geological Survey}

Du Noyer never settled in London. He may have thought that his fortune was to change in 1846, when Captain James was transferred to oversee famine relief works within the Board of Works, and Oldham was asked to take on the mantle of local director in Dublin. ${ }^{76}$ In May 1847, two years after establishment of the Geological Survey of Ireland, Oldham wrote to De la Beche saying that he had received three applications for a temporary position within the Geological Survey of Ireland, only one of which was eligible - that of Du Noyer who, according to Oldham, 'would make a good and useful assistant. He has some experience, is steady enough, very observant and tolerably well informed'. ${ }^{77}$ Du Noyer's working knowledge of geology evidently impressed Oldham sufficiently to appoint him to the position, on a pay of $10 \mathrm{~s}$. a day. This is despite the fact that Du Noyer was returned as an artist in Thom's Irish Almanac of that year. ${ }^{78}$ Oldham appointed him to work mapping (and therefore sketching, as sketching was the first stage of mapping) the geological cross-sections that were exposed by the laying of railway tracks. Oldham said that he would appoint him full-time to the role if the railway sections were satisfactory as he believed he was 'as good a man as we can hope to get'. ${ }^{79}$

With his temporary contract ending at the end of September 1848, Du Noyer wrote to De la Beche from Carnew, county Wicklow, to express his desire to be to be considered for a position as geological assistant within the Geological Survey, 'assuming [his] qualifications for the service would be of a character to justify' it and 'should circumstances permit'. ${ }^{80} \mathrm{De}$ la Beche replied on the following day:

Seeing that your engagement respecting the railway cuttings may be regarded as a sufficient testimonial for the requirements needed for an assistant geologist on the geological survey, that satisfaction has been given on that

\footnotetext{
${ }^{73}$ GSI, Incoming letters 1844-49/10, Lord Lincoln to Henry De la Beche, 21 May 1845.

${ }^{74}$ National Museum of Wales (NMW), De la Beche papers/1064, Thomas Oldham to Henry De la Beche, 15 July 1845 .

${ }^{75}$ NMW, De la Beche papers/1085a, Thomas Oldham to Henry De la Beche, 10 May 1847.

${ }^{76}$ Herries Davies, Sheets of many colours, 137.

${ }^{77}$ NMW, De la Beche papers/1085a, Thomas Oldham to Henry De la Beche, 10 May 1847.

${ }^{78}$ Thom's Irish Almanac and official directory, 1847.

${ }^{79}$ NMW, De la Beche papers/1085a, Thomas Oldham to Henry De la Beche, 10 May 1847.

${ }^{80}$ GSI, Incoming letters 1844-49/129, G.V. Du Noyer to Henry De la Beche, 28 Sept. 1848.
} 
special service and that circumstances do permit the addition of an assistant geologist, I have much satisfaction in appointing you to the geological survey as an assistant geologist at the rate of pay of $9 s$. per day for the six working days of the week in the usual manner, upon a six month trial. ${ }^{81}$

Du Noyer communicated this immediately to Oldham, who asked him to contact Andrew Wiley, assistant geologist, 'at present stationed at Carnew, who has the maps etc. necessary for the examination of that district and who has been instructed to afford you every information and instruction in his power'. ${ }^{82}$ Later in 1848, Du Noyer was under the instruction of Walter Willson, the second surveyor appointed to the Geological Survey of Ireland, and Oldham moved him to working on county Dublin. ${ }^{83}$ Oldham also encouraged his new assistant to engage fully with the geological life of Dublin, and he asked Du Noyer to present on his work on the geological cuttings of the Dublin and Belfast junction at the Geological Society in January of $1849 .{ }^{84}$

Du Noyer was under the impression that the $9 s$. on which he was employed was linked to his probation, and as this ended in April 1849, he wrote to De la Beche, requesting that his pay be 'reinstated in my former salary' of $10 \mathrm{~s}$. a day. ${ }^{85} \mathrm{He}$ mentioned to De la Beche that Oldham had twice expressed 'satisfaction at [his] progress'. ${ }^{86}$ De la Beche's reply was characteristically swift; Du Noyer's request was refused as De la Beche put it down to 'a misapprehension on [Du Noyer's] part' ${ }^{87}$ Oldham concurred. He likewise ascribed Du Noyer's request to a 'misconception of the arrangements connected with the Geological Survey', and admonished him somewhat for writing to De la Beche instead of directing the inquiry to him. Pay was 'decided solely by a consideration of the work performed and shall in due course be considered when the work executed by [Du Noyer] (...) shall have been carefully gone over' ${ }^{88}$ Du Noyer admitted his misunderstanding, apologising to both by return of post. ${ }^{89}$ Nonetheless, Oldham wrote to De la Beche recommending that Du Noyer's employment be continued after the probationary period as he had 'performed his duty steadily during that period and [appeared] anxious to improve and advance the interest of the same'. ${ }^{90}$

Du Noyer evidently impressed Oldham, who wrote in October 1849 to De la Beche to inform him that had contemplated raising Du Noyer's salary by the $1 s$. a day requested previously, but he had thought the better of it and would wait until January of the following year. ${ }^{91}$ True to his word, Oldham wrote in January of 1850 , reporting that 'Du Noyer has devoted himself steadily and zealously to his duties (...) and that the accuracy and character of his field work has much improved', and requesting a raise of pay of $1 s$. per day. ${ }^{92}$ This time, De la Beche acceded. Oldham saw this as an incentive for Du Noyer to continue to work with increased 'zeal and energy' for the survey. ${ }^{93}$

\footnotetext{
${ }^{81}$ GSI, Outgoing letters 1844-50/272, Henry De la Beche to G.V. Du Noyer, 29 Sept. 1848.

${ }^{82}$ GSI, Outgoing letters 1844-50/279, Thomas Oldham to G.V. Du Noyer, 1 Oct. 1848.

${ }^{83}$ NMW, De la Beche papers/1105, Oldham to De la Beche, 2 Dec. 1848.

${ }^{84}$ The Advocate, 13 Jan. 1849, 3.

${ }^{85}$ GSI, Outgoing letters 1844-50/317, G.V. Du Noyer to Henry De la Beche, 2 Apr. 1849.

${ }^{86}$ GSI, Outgoing letters 1844-50/317, G.V. Du Noyer to Henry De la Beche, 2 Apr. 1849.

${ }^{87}$ GSI, Outgoing letters 1844-50/320, Henry De la Beche to G.V. Du Noyer, 4 Apr. 1849.

${ }^{88}$ GSI, Outgoing letters 1844-50/322, Thomas Oldham to G.V. Du Noyer, 9 Apr. 1849.

${ }^{89}$ GSI, Outgoing letters 1844-50/324, G.V. Du Noyer to Henry De la Beche, 10 Apr. 1849; GSI, Incoming letters 1844-48/158, G.V. Du Noyer to Thomas Oldham, 10 Apr. 1849.

${ }^{90}$ GSI, Outgoing letters 1844-50/ 329, Thomas Oldham to Henry De la Beche, 3 Apr. 1849.

${ }^{91}$ NMW, De la Beche papers/1109, Oldham to De la Beche, 3 Oct. 1849.

${ }^{92}$ GSI, Outgoing letters 1844-50/378, Thomas Oldham to Henry De la Beche, 3 Jan. 1850.

${ }^{93}$ GSI, Outgoing letters 1844-50/377, Thomas Oldham to G.V. Du Noyer, 9 Jan. 1850.
} 
Oldham's advocating for Du Noyer is not surprising, as Oldham struggled to find sufficiently skilled field workers for the survey; of Wiley, the assistant with whom Du Noyer met on being appointed, Oldham wrote he "will never make a good field man. His total want of any system, his nearsightedness, and his extraordinary erratic habits unsuit him for this ${ }^{94}$ while he also wrote to De la Beche as having to go over and clarify work by Walter Willson. There was also the matter of money, as the frequent difference in costs between Willson and Du Noyer for the same item (Willson generally claiming more than Du Noyer) was the subject of some query from London. ${ }^{95}$ Oldham took over the mantle of guiding Du Noyer on the path of geology but shortly afterwards left to take up his position as director of the Geological Survey of India. ${ }^{96}$ Deep down, however, Du Noyer still harboured the desire to move to England. In a letter from John Kennedy to De la Beche in 1854, Kennedy speaks of Du Noyer as being 'very anxious to go to England' and his belief that J.B. Jukes, then the director of the Geological Survey of Ireland, would recommend him for a position there. ${ }^{97}$

During these years Du Noyer always carried a pocket notebook-'Harwoods' Improved Patent Memorandum Book with Metallic pencil' was his brand of choice in later years - into which he sketched and noted anything that caught his attention. Between 1847 and 1861 he used nine notebooks. The notebooks contain initial pencil sketches (many unfinished or in very preliminary state), notes on antiquities, personal remembrances and memos and even some notes on his expenditure - his notebooks were truly an aid for him as he traversed the countryside. The notebooks, unlike the scrap-books he later created, are chronological; although at times Du Noyer would forget which side of the notebook he began with, and would alternate between the front and back pages. Du Noyer compiled scrap-books later, organising the material geographically. He cut out some of the more complete sketches from the small notebooks, and placed them with more complete drawings on larger sheets, some of which were worked up to watercolour or (less regularly) oil paintings, side by side, along with a contents list at the beginning of each of the volumes. Thus, the scrap-books contain generally more completed works, sketches of landscapes, upstanding monuments, street scenes, and other items of interest. ${ }^{98}$ The scrap-books, therefore, are of greater artistic value than the smaller pocket notebooks. Some of these sketches he later apparently worked up further. Many of the sketches and watercolours within the albums Du Noyer presented to the Royal Irish Academy have their origin in sketches contained within the pocket notebooks and scrap-books (Plate I). Other sketches can be recognised as the source of lithographs for the memoirs of the Geological Survey of Ireland.

Du Noyer's style of geological sketching, which was for him a continuation of his work as an artist, was not without its limitations (Plate II). Those sketches of his which were to be used in the memoirs of the Geological Survey first had to be transferred to wood block, and then carved. The intricacy of Du Noyer's sketches meant that this was a laborious task, and cost money. By the late 1860s, Du Noyer was putting in so much detail into these drawings that the director of the Geological Survey remarked: 'your style of minute shading and finish makes the wood engraving excessively troublesome, while a better effect could be produced by a slighter and broader treatment. This has always appeared to me to be the case. ${ }^{99}$ Du Noyer must have been somewhat perturbed by the suggestion that the drawings he had completed at the back of his field sheets, which he considered preparatory sketches, or

\footnotetext{
${ }^{94}$ NMW, De la Beche papers/1109b, Oldham to De la Beche, 3 Oct. 1849.

${ }^{95} \mathrm{Cf}$. NMW, De la Beche papers/1124, Oldham to De la Beche, 16 July 1850.

${ }^{96} \mathrm{NMW}$, De la Beche papers/1110a, Oldham to De la Beche, 12 Oct. 1849.

${ }^{97}$ NMW, De la Beche papers/0833a, John Kennedy to Henry De la Beche, 24 Aug. 1854.

${ }^{98}$ Both the notebooks and the scrap books are held by the Royal Society of Antiquaries of Ireland. In total, there are 13 notebooks and 12 scrap books.

${ }^{99}$ GSI, Outgoing letters 1862-78/312, J.B. Jukes to G.V. Du Noyer, 16 May 1868.
} 
for the purpose of aiding interpretation of the rock formations by the survey geologists, would be sufficient for the memoirs. ${ }^{100}$ Du Noyer's landscape lithographs, and many other illustrations that had hitherto been used to illustrate the memoirs of the Geological Survey, began to disappear from the memoirs as the directors decided that all illustrations should be instructional, and not ornamental. ${ }^{101}$ Du Noyer, however, did not want to simplify his work, and to resolve the issue of the cost of engraving, asked for the wood blocks to be sent to him for engraving. The director refused. ${ }^{102}$

Within the Geological Survey, the lack of 'formal' geological knowledge of some of the staff occasionally raised eyebrows at headquarters. Following Oldham's appointment to the Geological Survey of India, Joseph Beete Jukes (1811-69) was assigned the directorship of the Geological Survey of Ireland in 1850 (Plate III). At the beginning of the 1850s, Jukes commented; 'Our fellows here seem all good fellows, as good as on the English survey, but sometimes they do astound me not a little and then that leaves an uncomfortable feeling afterwards'. ${ }^{103}$ Indeed, Du Noyer himself seems to have been unsure at times in his geological knowledge, particularly early on in his time at the Geological Survey. This is little wonder, as he took pride in his work, and yet knew that all of his training, and indeed his work in the geological department in the Ordnance Survey, had been in sketching rather than in the interpretation of rocks. In his personal notebooks in March 1851 we find him writing what he terms a 'parody' on Shakespeare's song 'Tell me where is fancy bred' from the Merchant of Venice:

Tell me, tell me, oh,

Tell me what to call this rock.

Is it old red shale or is it red slate?

Tell me, tell me, tell me,

How formed, how hardened,

Reply reply.

It was engendered 'neath the sky

By torrents fed its matter lies

Now weathering 'neath one sky

By heat internal cleaved

Brown grains its mark took

Which old red doth emulate

But set it down as slate

But set it down as slate. ${ }^{104}$

Perhaps conscious of his own limitations, Du Noyer was avid for information about geology. During a trip to Paris, possibly in 1857, he copied into his notebook a geological stratigraphy of France which was being sold by the prominent cartographic publishers J. AndriveauGoujon. ${ }^{105}$ Later in the same notebook he compiled a geological stratigraphy of Irish rocks, from the Lower Silurian (which he notes as 'Chair of Kildare rocks') to the conglomerates of the Old Red Sandstones. While in the field, he continued sketching the archaeology and landscapes (both rural and urban) he passed through in his pocket notebook. Within his

\footnotetext{
${ }^{100}$ Cf. GSI Outgoing letters 1862-78/323, J.B. Jukes to G.V. Du Noyer, 29 May 1868; GSI, Outgoing letters 1862-78/330-1, J.B. Jukes to G.V. Du Noyer, 3 June 1868.

${ }^{101}$ GSI, Outgoing letters 1862-78/323, J.B. Jukes to G.V. Du Noyer, 29 May 1868.

102 GSI, Outgoing letters 1862-78/330-1, J.B. Jukes to G.V. Du Noyer, 3 June 1868.

103 J.B. Jukes to Andrew Ramsay, 31 May 1851, quoted in Herries Davies, Sheets of many colours, 160.

${ }^{104}$ RSAI, G.V. Du Noyer sketches, notebook 3, Mar. 1851.

${ }^{105}$ RSAI, G.V. Du Noyer sketches, notebook 11.
} 
personal notebooks, he also noted down the headings under which the descriptions within the memoirs were to be collected, possibly as an aid to his mapping, as well as other geological notes. ${ }^{106}$

As his time in the Geological Survey progressed, so did Du Noyer's confidence and his geological knowledge. In 1864, the Geological Survey instituted the grade of District Surveyor, a post designed to allow more senior members to have an overview of the training and work of junior staff. Du Noyer was the first appointment to the position of Irish District Surveyor. ${ }^{107}$ From entering the Geological Survey as an artist with some experience in field mapping (albeit at under the apprenticeship of some of the key figures of geology of his time), he was now training new members of the Geological Survey in the science and art of geology, and inspecting their work. He may have performed his duties responsibly but Jukes was not convinced that Du Noyer's geological knowledge was sufficient. The differences in personality between these two men caused a few awkward encounters, most notably in 1862, and again in 1867. On the first of these occasions, Du Noyer had removed worked maps from the Geological Survey office in Dublin, without the sanction of Jukes and therefore against Survey rules, and brought them to his brother-in-law in Killaloe, county Clare, who was interested in the slate quarries of that area. ${ }^{108}$ This led to a robust correspondence between the two men, with Jukes admonishing Du Noyer for his being absent without leave and his removal of the maps, especially for a private purpose. ${ }^{109}$ The strain on their relationship was again evident just two years before Du Noyer's death. In a letter in which Jukes called Du Noyer's attention to the accuracy of his interpretation of an outcrop at Scrabo Hill (Plate IV), county Down, he wrote:

I beg leave to call your attention in an official form which will be kept among our records to some parts of your conduct lately which seem to me to render it doubtful how far you can continue to hold your present post. I have frequently had occasion during the last few years to point you to your errors and irregularities in the mode of keeping your accounts and filling up our forms (...) I have also had to show your absurdities in your geological work which the merest tyro ought not to have committed, and at the present moment on my table a pile of your Mss. for the explanations of some of the Wicklow maps which it would be impossible to commit to press. (...) A still more striking case is that you have described and colour on our maps, as New Red Sandstone, a tract of country near Newtownards including the well-known Scrabo Rock, which is utterly unlike any New Red Sandstone in any part of the British Islands. (...) On visiting them the other day I immediately saw the mistake you had made and wrote you a letter explaining the real structure of the ground to you. To this letter you sent me a hastily written reply, maintaining your own correctness, requiring me to meet you on the ground and prove my assertions by palaeontological evidence and using other wild and extravagant expressions. (...) In a subsequent letter acknowledging your mistake you excuse it by saying that your copy of (Sir Richard Griffith's) map is blurred. It appears then that you have not sufficient knowledge of ordinary geology to enable you to make your own observations on the country you are

\footnotetext{
${ }^{106}$ RSAI, G.V. Du Noyer sketches, notebook 12, Notes on headings for descriptions of one-inch maps, 19 May 1858.

${ }^{107}$ John Smith Flett, The first hundred years of the Geological Survey of Great Britain (London, 1973), 75;

Edward Baily, The Geological Survey of Great Britain (London, 1952), 76.

${ }^{108}$ GSI, Outgoing letters 1862-78/6-7, J.B. Jukes to G.V. Du Noyer, 1 Apr. 1862.

${ }^{109}$ GSI, Outgoing letters 1862-78/9-10, J.B. Jukes to G.V. Du Noyer, 24 Apr. 1862.
} 
now examining but prefer to take as an authority a blurred copy of Sir R. Griffith's small map. As circumstances obliged me to acquiesce in your appointment to this new office of District Surveyor I shall not make the present occasion the ground of any movement respecting it, but content myself with seriously warning you to exercise more care and caution for the future, to be on your guard against your own manifest deficiencies so as not to compel me to bring them under the notice of the Director General and if you cannot give me the assistance which you ought, at least to avoid giving me unnecessary trouble. ${ }^{110}$

Du Noyer's interpretation of the rocks was correct, and the area around Scrabo Hill was mapped as New Red Sandstone on the Geological Survey's one-inch map, with some Greenstone (later mapped as diorite) also outcropping. ${ }^{111}$ Later in October 1867, his interpretation of rocks at Cultra Cottage, to the north of Scrabo Hill, was corrected by Jukes, this time justifiably. ${ }^{12}$ Subsequent letters in late 1867 and early 1868 between Jukes and Du Noyer testify to rising tensions between the two men as a result of Jukes' requests for maps to be sent for inspection, and Du Noyer's assumption that he could act more independently in his capacity of District Surveyor, something that Jukes was quick to dismiss. ${ }^{113}$ Although at times his lack of geological knowledge made his superiors nervous, Du Noyer had become a competent field geologist, his artist's eye picking out details which had been hitherto overlooked. Several months after his querulous initial query about Du Noyer's interpretation of Scrabo Rock, Jukes acknowledged:

I have to withdraw the assertion that you were wrong in considering the sandstone near the top of Scrabo Hill (near Newtownards) to be New Red Sandstone (...) I must also state that the numerous inaccuracies of observation and interpretation which I have observed in your work lately had bred in me a great distrust of your powers in both departments of work. At my last interview with you, in the office, you professed that you felt you were a different man from what you were twelve months ago. This profession and the excellent style of work you seem now to be doing in your present district tend greatly to remove the distrust alluded to above, and relieves my mind of a feeling of despair that had begun to take possession of it, as to how I was possibly to perform the work that is now thrown upon me in both my offices. ${ }^{114}$

Subsequent letters to Du Noyer by Jukes are addressed to 'My dear Mr Du Noyer' rather than the 'Sir' Jukes had previously used as a salutation, indicating that the difficulties that had characterised their relationship were resolved. ${ }^{115}$

\section{Desiring recognition-membership of the Royal Irish Academy}

Throughout his time on the Geological Survey Du Noyer continued sketching. Just as had occurred during his time at the Ordnance Survey, his engagement with archaeological

\footnotetext{
${ }^{110}$ GSI, Outgoing letters 1862-78/278-9, J.B. Jukes to G.V. Du Noyer, 19 Oct. 1867.

${ }^{111}$ GSI, 1: 63,360 geological map series, sheet 37 (1869).

112 GSI, Outgoing letters 1862-78/244-5, J.B. Jukes to G.V. Du Noyer, 26 Oct. 1867.

${ }^{113}$ GSI, Outgoing letters 1862-78/277-9, J.B. Jukes to G.V. Du Noyer, 27 Feb. 1868; 5 Mar. 1868.

${ }^{114}$ GSI, Outgoing letters 1862-78/296, J.B. Jukes to G.V. Du Noyer, 22 Apr. 1868.

${ }^{115}$ GSI, Outgoing letters 1862-78/327, J.B. Jukes to G.V. Du Noyer, 3 Jun. 1868; 5 Jun. 1868.
} 
material while at the Geological Survey was not regarded favourably. When Du Noyer wrote in 1868 to ask for four days' allowance to visit Antrim, Jukes replied:

May I be allowed to ask with what object you wish so particularly to visit Antrim for four days now? I am induced to make this inquiry by the reception of the catalogue of worked flints which you have sent. Such a line of investigation is archaeological, rather than geological, and experience of former occasions by no means encourages me to allow you to spend survey time in such investigation. ${ }^{116}$

Nonetheless, Du Noyer continued to sketch (Plate V). As was his established practice, many of the sketches that survive in his pocket notebooks were preliminary drawings for more complete works he would publish in the Memoirs of the Geological Survey of Ireland, or watercolour drawings he would present to the Royal Irish Academy. It could be said that in spite of his geological work, Du Noyer was above all else an artist, and an artist of antiquities, architecture and archaeology. He was a geologist by profession, and an artist by temperament. His interest in these fields also led him to continue publishing in archaeology, and, like many of his contemporaries, to add information about archaeological finds to his geological field maps.

On 14 August 1857, Du Noyer was elected to membership of the Royal Irish Academy. In his certificate of candidature, his qualifications are listed as 'author of papers in the Journal of the Geological Society of Dublin and in the Journal of the Archaeological Institute of Great Britain'. ${ }^{117}$ His main proposer was J. Beete Jukes, the director of the Geological Survey of Ireland. The other gentlemen who joined in his nomination were Robert Callwell, Henry Coulson Beauchamp, Samuel Ferguson, Edward Wright, Robert Wills Wilde, Rev. James H. Todd and Rev. Humphrey Lloyd. It is noteworthy that his proposers were antiquarians and historians rather than geologists (the exception being Jukes). Noteworthy also is the absence of the name of George Petrie on the transcript.

As mentioned above, Du Noyer's background meant that he did not quite feel he belonged to any particular community. He was an artist working as a geologist, or perhaps a geologist who painted and sketched, with an interest in archaeology. He was a Huguenot, a native French speaker born and bred in an English-speaking city, belonging to a minority people within the larger minority of the Church of Ireland. It was natural, therefore, that Du Noyer sought the recognition of his peers. The Royal Irish Academy had been purchasing archaeological drawings from Du Noyer on a regular basis since $1841 .{ }^{118}$ Having identified that they were interested in adding to their material on Irish antiquities, and within a context where archaeology and antiquarianism was acquiring a political importance linked to romantic nationalism, Du Noyer perfected some of the sketches he had taken in the field and created watercolours of the antiquities, archaeological artefacts and landscapes. ${ }^{119} \mathrm{He}$ presented eleven folios of drawings and sketches to the RIA between 1859 and 1863 . He accompanied each of the folios with an explanation of the sketches within the books. These explanations were published in the Proceedings of the Royal Irish Academy in the years of their presenting, each text containing a simple description of the location the sketch

\footnotetext{
${ }^{116}$ GSI, Outgoing letters 1862-78/280, J.B. Jukes to G.V. Du Noyer, 6 Mar. 1868.

${ }^{117}$ RIA, MRIAC/413, Royal Irish Academy Certificate of Candidature.

118 'Appendix No. II: Account of the Royal Irish Academy from 1st April 1841 to 31st March 1842' PRIA (1836-1869), 2 (1840), xii.

${ }^{119}$ Crooke, Politics, archaeology and the creation of a National Museum of Ireland, 103. All the pocket notebooks of Du Noyer are housed in the Royal Society of Antiquaries of Ireland.
} 
represents. ${ }^{120}$ While these folios were received by the Academy as a generous donation-'his contributions, the numerous sketches which he so spontaneously offered to the Academy, were the fruits of his leisure moments during his geological wanderings' was how Gages phrased it in a biographical note to the RIA after Du Noyer's death - there may have been a deeper, more personal motivation. ${ }^{121}$ In a telling entry in his personal notebooks, possibly made in 1857 judging by the adjacent entries, Du Noyer wrote

Recollect that the collection of sketches is worth the Academy securing, it is worth their while to listen to what you have to say. Recollect the manner of delivery of Carmichael ${ }^{122}$ - slow - clear - simple - Think only of the drawings. Take your time - Think of Dr Reeves and the[n] life membership. Steady. Recollect that you must look on the people around you as so many tables and chairs. Do not let them laugh at you. ${ }^{123}$

Du Noyer, in short, appears to have placed a value beyond that of the artistic worth, and archaeological value on the drawings he presented. They were, for him, a means of recognition as a scholar, by paving the way for securing life membership of the Royal Irish Academy. Du Noyer would have known that Petrie was elected a life member after offering the original of the second part of the Annals of the Four Masters to the Academy for the original cost price of $£ 70$ he had paid at auction in 1831, although Petrie was offered any amount of money he wished by other parties for the manuscript. ${ }^{124}$ Du Noyer longed for the same recognition. These sentiments find something of an echo in the note he wrote to the Academy on the presentation of some of the drawings:

If as yet I have not been able to contribute as worthily as I would wish to the Academy's publications, I at least can enjoy the pleasure of aiding by my pencil others more versed in antiquarian research than I can ever hope to be, and in this way help to record, in as faithful a manner as I am capable of, an interesting class of relics, some of which have been preserved in Ireland from the earliest Christian times, and which are not surpassed in Northern Europe for quaintness or originality.

My object in making this presentation to the Library of the Academy arises from a wish to increase its value to the antiquary; and I think it only right that these drawings should not be usable, except under the same conditions as those imposed on our manuscripts. The only personal reward which I venture to seek is, that those gentlemen who may find occasion to copy from them, or

\footnotetext{
${ }^{120}$ G.V. Du Noyer, Description of drawings of Irish antiquities presented by him', PRIA (1836-1869), (1857), vii, 249-62; G. V. Du Noyer, 'Description of drawings of Irish antiquities presented by him (continued)', PRIA (1836-69), vii (1857), 302-16; G.V. Du Noyer, 'Catalogue of 95 antiquarian drawings presented to the Academy', PRIA (1836-69), 8 (1861), 282-9; G.V. Du Noyer, 'Description of Antiquarian Drawings’ PRIA (1836-69), viii (1861), 61-7; G.V. Du Noyer, 'Catalogue of drawings from original sketches of antiquities in the counties of Westmeath, Longford, Meath, and King's County', PRIA (1836-1869), ix (1864), 148-60; G. V. Du Noyer, 'On architectural sketches presented by G.V. Du Noyer, Esq.' PRIA (1836-1869), x (1866), 89-100; G. V. Du Noyer, 'On original sketches of coats of arms presented by Geo. V. Du Noyer, Esq.', PRIA (18361869), x (1866), 179-88.

${ }^{121}$ Gages, 'Biographical Notice of the Late George V. Du Noyer, Esq', 413-4.

122 The mathematician Rev. Robert Bell Carmichael had presented a paper to the Royal Irish Academy in November 1857 on 'Brief methods in Integral Calculus'. His style of delivery evidently impressed Du Noyer. ${ }^{123}$ RSAI, Du Noyer notebook 8.

${ }^{124}$ Walsh, George Petrie: his life and work, 48.
} 
otherwise use them, will have the courtesy to mention the source from whence their information was derived. ${ }^{125}$

We can see in this something of the desire Du Noyer harboured to contribute 'worthily' to the Academy's business; although it can be argued that his act of generosity was due to a little more than a wish to increase the holdings of the Library.

Du Noyer was made a life member of the RIA in 1863. Thus, Du Noyer ultimately achieved the goal he had set himself, and achieved it through his artistic works (on antiquarian subjects) rather than as a result of his work as a geologist within the Geological Survey. Nonetheless, his knowledge of the geology of the districts he surveyed was such that he published in the journal of the Geological Society and wrote sections of seventeen memoirs of the Geological Survey of Ireland. His illustrations were used in the memoirs of the Geological Survey even after his death.

\section{Conclusion}

George Victor Du Noyer died of scarlet fever in January 1869, a day after his daughter succumbed to the same illness. He was 52, and not yet of pensionable age. His widow, Frances, did not receive any financial help on the death of her husband. Jukes petitioned the then head of the Geological Survey, Roderick Murchison (1792-1871), for financial aid from the scientific relief fund of the Royal Society of London for the widow and orphans of an 'indefatigable worker'. ${ }^{126}$ Murchison replied with a grant of $£ 50$ from the fund. ${ }^{127}$ This was not sufficient for the family, who were 'left so wretchedly off'. ${ }^{128}$ Despite a letter from the scientific community conveyed through the Royal Irish Academy to William Gladstone, the First Lord of the Treasury, requesting a pension for Du Noyer's widow, payment was never forthcoming. In an effort to aid the widow of one who had given himself so completely to the pursuit of knowledge, the community interested in antiquities purchased from Frances Du Noyer all of George Victor's sketch notebooks and scrapbooks for 'a price substantially exceeding the stipulated price'. ${ }^{129}$ Nonetheless, the family continued to experience financial difficulties, and two years after Du Noyer's death, in 1871, his eldest son, also called George (George A.), was admitted to the Masonic Orphan's Boys' School in Dublin. ${ }^{130}$ In 1876 George A. Du Noyer was still at the school, obtaining first class in Scripture that year. ${ }^{131} \mathrm{Du}$ Noyer had gained recognition from his peers, he had gained life membership of the Royal Irish Academy, yet his premature death left his family in difficulties. The connections he made throughout his life, however, rallied to support his family after his death. Du Noyer had found acceptance, beyond the labels of 'artist' or 'geologist'.

\footnotetext{
${ }^{125}$ G.V. Du Noyer, 'Description of drawings of Irish antiquities presented by him', PRIA (1836-1869), 7, 1857, $261-2$.

${ }^{126}$ GSI, Outgoing letters 1862-78/373, J.B. Jukes to Roderick Murchison, 1 Feb. 1869

${ }^{127}$ Croke, George Victor Du Noyer, 15.

${ }^{128}$ GSI, Outgoing letters 1862-78/370, J.B. Jukes to J. Reeks, 25 Jan. 1869.

129 James Graves, Secretary's Report, Proceedings, January meeting, The Journal of the Royal Historical and Archaeological Association of Ireland, fourth series, i, (1870), 5-6.

${ }^{130}$ Dublin Evening Mail, 30 Sept. 1871, 3.

${ }^{131}$ Dublin Evening Mail, 29 Apr. 1876, 3.
} 